\begin{tabular}{|c|c|c|}
\hline \multirow{2}{*}{ IDUNAS } & NATURAL \& APPLIED SCIENCES & 2020 \\
& Vol. 3 \\
No. 1 \\
$(40-46)$
\end{tabular}

\title{
The Effect of Different Workout Programs on the Expression of the Genes Related to Oxidative Stress and Immune System
}

\author{
Research Article

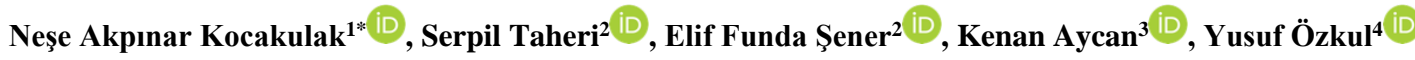 \\ ${ }^{1}$ İzmır Democracy University, Faculty of Health Sciences, Department of Sport Sciences, İZMIR/TURKEY \\ ${ }^{2}$ Erciyes University, Faculty of Medicine. Department of Medical Biology, KAYSERI/ TURKEY \\ ${ }^{3}$ Erciyes University, Faculty of Medicine. Department of Anatomy, KAYSERI/ TURKEY \\ ${ }^{4}$ Erciyes University, Faculty of Medicine. Department of Medical Genetics, KAYSERI/ TURKEY \\ Author E-mails \\ nese.kocakulak@idu.edu.tr \\ *Correspondance to: N. Akpınar Kocakulak, İzmır Democracy University, Faculty of Health Sciences, \\ Department of Sport Sciences, İzmir/Turkey \\ Tel: +902322601001 \\ DOI:10.38061/idunas.726846
}

Received: April 25, 2020; Accepted: June 25, 2020

\section{Abstract}

Background: exercise conditions can affect the expression of genes. Our study investigated the effects of acute and chronic exercise on the expression of genes related to oxidative stress (Tfam, UCP2, UCP3) and immune system (IL-1 $\alpha$, IL-1 $\beta$, IL-2, IL-8, IL12A, IL12B, TLR2, TLR4).

Methods: was formed with 24 people: 12 healthy females and 12 healthy males. Maximal oxygen use capacities of the participants were determined by the Bruce test protocol at the beginning and end of the 8week training program. After calculating their maximal oxygen use capacity, each participant was given an acute running exercise on the tread mill at the speed and incline that the participant would reach to his/her maxVO2 until exhausted. The same people was built to continuous runs (50-70\%) for 8 weeks in a week, and two days of intermediate interval training program ( $80 \%$ and above). Venous blood samples were taken before and after acute exercise with immediately after chronic exercises. RNA isolation was performed using TRIzol Reagent from peripheral blood mononuclear cells. Gene expression was determined by Biomark Real-Time PCR (RT-PCR). Comparisons were performed by using two independent sample t-test and Mann-Whitney $U$ for quantitative data and calculated gene expression values. The statistical significance level was taken as $\mathrm{p}<0,05$. Results: we found that acute exercise in women changed Tfam gene expression $(\mathrm{p}<0,05)$. Chronic exercise changes the expression level of more genes (Tfam, IL-1 $\beta$, TLR4) in women $(\mathrm{p}<0.05, \mathrm{p}<0.001)$. There was only difference in Tfam gene in males $(\mathrm{p}<0,05)$. Conclusions: changes in gene expression differed by sex in exercise. Our results indicate that different workout programs for females and males cause genes to work and they have a positive effect on their expressions and thus increase the efficiency of the exercise.

Keywords: Exercise, Gene Expression, Immune System, Oxidative Stress 


\section{INTRODUCTION}

The effects of exercise on the immune system have begun to be examined especially in recent years and many studies have been carried out on this subject (Ntanasis, 2013, Meier, 2013, Bangi, 2000). While the results from these studies do not yet reveal the exact clinical relevance, long-term intensive exercises increase susceptibility to infections. Clinically, upper respiratory tract infections are usually reported after exhausting exercise (Eynon, 2009, De Nadal, 2011). Because of their basic role in the immune system, cytokines are one of the important research topics in physical exercise. A significant proportion of the cytokines secreted from the immune system are interleukins and their primary task is to stimulate the immune system cells. They are released temporarily in various immunologic, infectious and inflammatory diseases and it is indicated that plasma levels of cytokines such as IL-6, IL-1 $\beta$, and TNF-alpha are increased especially in exhausting acute exercises (Flynn, 2003). Studies have shown that approximately 2 hours of daily regular moderate exercise reduces upper respiratory tract infection at compared to sedentary lifestyle, but this risk increases with intensive ultra exercises (LuzScheffer, 2019). Toll-like receptor (TLR), which is one of the key molecules in the immune system's defense against microbial infections, is an important contributor to the development of adaptation in the immune response to the monocyte, macrophage and dendritic cells. The activation of TLR receptor stimulates both the production of inflammatory cytokines such as IL-1 $\beta$, IL-6, IL-8, and TNF- $\alpha$, and the innate immune system. Studies report that TLR receptor increases in acute and chronic endurance exercise (Kumar, 2009, Lancaster, 2005). It has been reported that reactive oxygen species increase with the production of some immunity cell functions during the exercise. During long-term/intensive exercise, the amount of oxygen consumed changes depending on the intensity and type of the exercise, but in general, it causes the emergence of the free radicals (reactive oxygen species, ROS) that cause oxidative stress by increasing considerably compared to relaxation. In addition, ROSs plays an important role in regulation of cell signaling and gene expression (Kocakulak, 2020, Kocakulak, 2019). Physical exercise is seen as the reason of the changes in the skeleton muscle genes expression of a many people. However, it is not known exactly which mechanism regulates gene expression of important genes involved in metabolic stress or metabolic adaptation (Gleeson, 2007, Borras, 2003). The purpose of this study is to investigate the effect of the acute and chronic exercises on the possible changes that can occur in the expressions of 7 genes selected as being related to oxidative stress (Tfam, UCP2, UCP3) and immune system (IL-1 $\beta$, IL12B, TLR2, TLR4). Thus it has been tried to explain if the increases and decreases in the expression levels of these genes are related to exercises.

\section{METHODS}

Study Group: The research was conducted with total 24 people, 12 of whom were healthy females and 12 healthy males. Subjects who do not exercise regularly, do not smoke, do not take any additional nutrients are included in the study. Our study protocol was approved by Erciyes University Ethical Committee and the study was conducted in accordance with Helsinki Declaration and local law (No:2012/68). Maximal Aerobic Capacity (ن்2 max): The maximal oxygen-using capacities were determined proportionally by applying the Bruce Test Protocol (Bruce, 1949). The first blood sample was taken to measure the resting values of the volunteers after calculating the amount of oxygen consumed (V்o max) and 2 days later. After 10 minutes of warm-up and stretching exercise, maximal exercise running test was applied. Maximal exercise running test: According to the Bruce Test Protocol, each participant did the running exercise until it was exhausted, at the speed and slope it reached to $\dot{V}_{0} 2$ max. Exercise participants It was completed by taking its own declarations and looking at the target heart rate (220-age). Blood samples were taken after exercise to determine the effect of acute exercise. Then 8 weeks of continuous runs and medium interval training started. Training program: The participants participated in the training program 3 days (Monday, Wednesday, Friday) a week for 8 weeks. Continuous Running Training Method: The participants were given a running exercise 1 day per week for 8 weeks between 25-60 min and 50-70\% of 
the target heart rate. Intermediate interval training program: The participants were given intermediate interval training program 2 days a week, for 8 weeks. The heaviness of the training was determined depending on the ( $80 \%$ and above) target heart rates of the volunteers. The scope of the training was determined as 4800 meters. The amount of oxygen consumed after the training was finished was recalculated. After 2 days, maximal exercise running test was applied and $10 \mathrm{ml}$ venous blood samples in tubes having EDTA were taken exercise after to see the effect of chronic exercise. The heights, weights, systolic and diastolic blood pressures and heart rates of the participants was recorded before and after from maximal exercise running test.

RNA Isolation and gene expression studies: Genetic studies were carried out at Erciyes University Genome and Stem Cell Center. RNA was isolated from $2 \mathrm{ml}$ blood samples taken from the groups (TRIzol, Roche, Germany) (Nilsson, 2008, Bayram, 2016). The quality and quantity of RNA was measured by BioSpec-Nano Spectrometer. Complementary DNA (cDNA) was obtained from RNA by RT2 HT First Strand (Qiagen) kit. While complementary DNA was being synthesized, it was left $42^{\circ} \mathrm{C} 15$ min and $95^{\circ} \mathrm{C}$ 5 min incubation. Gene expressions were determined by Biomark Real-Time PCR (RT-PCR). Biomark Real-Time PCR (Qiagen) was used for expression study. While expression study was being held, it was incubated at $95^{\circ} \mathrm{C} 10 \mathrm{~min}$ and throughout 40 cycles $95^{\circ} \mathrm{C} 15 \mathrm{sec}, 60^{\circ} \mathrm{C} 60 \mathrm{sec}$. Each sample was worked on twice and Glyceraldehyde-3-phosphate dehydrogenase (GAPDH) was selected as the housekeeping gene. Delta delta $\mathrm{Ct}$ method (2- $\Delta \Delta \mathrm{CT}$ ) was used for the relative quantification of the samples that were normalized by Glyceraldehyde-3-phosphate dehydrogenase (Jemiolo, 2004, Catoire, 2012).

Statistical Analysis: Data was collected with Biomark Real Time PCR analysis software using linear baseline correction method and auto global $\mathrm{Cq}$ threshold method. First, each gene was extracted from each gene expression control gene expression. These values are kept as $\Delta \mathrm{CT}$. The maximum $\Delta \mathrm{CT}$ value of that gene was then subtracted from each sample $\Delta \mathrm{CT}$ value for each gene. $\Delta \Delta \mathrm{CT}$ values were obtained at this point. System given $\mathrm{Cq}$ values of 999 and values larger than 23 haploid genome equivalents (HGEs) was considered as unreliable and removed. GeNORM was used to evaluate the expression stability of genes, and Glyceraldehyde-3-phosphate dehydrogenase (GAPDH) was used to normalize the RT-PCR data as an internal control. Data normalization was performed by using the $2-\Delta \Delta C T$ method. For all 8 groups, all binary comparisons were performed using the Mann-Whitney U test with calculated gene expression values. Statistical significance level was taken as $\mathrm{p}<0,05$. 


\section{RESULTS}

The average age of the participants was $21.88 \pm 2.44$ years for females and $23.8 \pm 4.1$ years for males, and the average height was $162.13 \pm 5.83 \mathrm{~cm}$ for females and $174.7 \pm 6.9 \mathrm{~cm}$ for males (Table 2).

Table.2. Some physical and physiological characteristics of the participants

\begin{tabular}{|c|c|c|c|c|c|}
\hline Variables & Groups & $\begin{array}{l}\text { Bruce test BE } \\
\text { Avg } \pm \text { SD }\end{array}$ & $\begin{array}{l}\text { 2.Bruce test AE } \\
\text { Avg } \pm \text { SD }\end{array}$ & $\mathrm{t}$ & $\mathrm{P}$ \\
\hline \multirow{2}{*}{ Weight (kg) } & Female $(n=12)$ & $58.60 \pm 2.04$ & $56.24 \pm 1.65$ & 4.2 & $0.001 * *$ \\
\hline & Male $(n=12)$ & $72.1 \pm 9.7$ & $71.3 \pm 9.5$ & 1.6 & 0.116 \\
\hline \multirow{2}{*}{ BMI $\left(\mathrm{kg} / \mathrm{m}^{2}\right)$} & Female $(n=12)$ & $22.29 \pm 2.43$ & $21.37 \pm 1.98$ & 4.5 & $<0.001$ *: \\
\hline & Male $(n=12)$ & $23.5 \pm 2.5$ & $23.3 \pm 2.3$ & 1.6 & 0.117 \\
\hline \multirow{2}{*}{$\begin{array}{l}\text { Heart Rate } \\
\text { (rate/min) }\end{array}$} & Female $(n=12)$ & $86.70 \pm 6.7$ & $98.90 \pm 7.98$ & 5.3 & $0.001 * *$ \\
\hline & Male $(n=12)$ & $81.60 \pm 8.4$ & $98.20 \pm 6.32$ & 5.1 & $0.001 * *$ \\
\hline \multirow{2}{*}{ Max VO2 } & Female $(\mathrm{n}=12)$ & $35.74 \pm 2.5$ & $46.16 \pm 3.25$ & 5.1 & $0.001 * *$ \\
\hline & Male $(n=12)$ & $51.8 \pm 4.7$ & $56.5 \pm 3.3$ & 4.8 & $0.001 * *$ \\
\hline
\end{tabular}

Paired Samples T Test / SD.: Standarddeviation $/ * \mathrm{p}<0.05 * * \mathrm{p}<0.001$

B.E.=Before Exercise A.E.=After Exercise BMI= Body Mass Index

According to the statistical analysis results, it was found that heart rates increased significantly in both females and males after exercise $(\mathrm{p}<0.001)$. After exercise, body weights $(\mathrm{p}<0.001)$ and body mass index $(p<0.000)$ decreased significantly in females. No difference was found in males $(p>0,05)$. The changes in the expression of 7 genes related to oxidative stress (Tfam, UCP2, UCP3), immune system (IL12B, IL-1 $\beta$, TLR2, TLR4) are shown in the following tables.

Table 3. Change in gene expression before and after acute maximal exercise protocol in women and men.

\begin{tabular}{|l|l|l|l|l|}
\hline Gene & Groups & $\begin{array}{l}\text { BE- F Median - } \\
\text { IQR }\end{array}$ & $\begin{array}{l}\text { AE- F Median - } \\
\text { IQR }\end{array}$ & P-value* \\
\hline \multirow{2}{*}{ fam } & Female & $5.48 \pm 2.387$ & $6.683 \pm 1.48$ & $\mathbf{0 , 0 2 0} *$ \\
\cline { 2 - 5 } & Male & $7.909 \pm 1.22$ & $7.846 \pm 0.593$ & 0,713 \\
\hline
\end{tabular}

Mann Whitney U test / IQR: Interquartile range $* \mathrm{p}<0.05$ B.E.=Before Exercise A.E.=After Exercise

There was an increase in Tfam gene expression after exercise in women. $(\mathrm{p}<0.05$, Table. 3$)$.

Table 4. Change of gene expression before and after 8 weeks training program in both women and men.

\begin{tabular}{|c|c|c|c|c|}
\hline Gene & Groups & $\begin{array}{l}\text { BE- F Median - } \\
\text { IQR }\end{array}$ & $\begin{array}{l}\text { AE - F Median - } \\
\text { IQR }\end{array}$ & P-value* \\
\hline \multirow[t]{2}{*}{ Tfam } & Female & $5.48 \pm 2.387$ & $7.773 \pm 0.216$ & $\overline{\mathbf{0 , 0 0 0} * *}$ \\
\hline & Male & $6.298 \pm 2.373$ & $7.887 \pm 0.363$ & $0,039 *$ \\
\hline \multirow[t]{2}{*}{$I L-1 \beta$} & Female & $14.993 \pm 3.2$ & $1.997 \pm 11.629$ & $0,001 * *$ \\
\hline & Male & $11.283 \pm 3.321$ & $0.5 \pm 12.345$ & 0,228 \\
\hline \multirow[t]{2}{*}{ TLR4 } & Female & $2.863 \pm 0.38$ & $3.364 \pm 0.332$ & 0,019* \\
\hline & Male & $3.598 \pm 0.448$ & $3.834 \pm 0.283$ & 0,151 \\
\hline
\end{tabular}

Mann Whitney U test / IQR: Interquartile range $* \mathrm{p}<0.05 * * \mathrm{p}<0.001$ B.E. $=$ Before Exercise A.E. $=$ After Exercise

There was a significant change in Tfam, IL-1 $\beta$, TLR4 gene expression after 8-week training program compared to pre-exercise in females. There was only one gene difference in males. $(* \mathrm{p}<0.05$ Table 4). 


\section{DISCUSSION}

Exercises have both positive and negative effect on immune system. After extended heavy exercises, minor diseases especially such as sore throat and flu are more frequent in athletes compared to the general population. Due to the high incidence of increasing of the breathing depth, exposure to the pathogens in the air also increases (Kocakulak, 2020). In our study, it is seen that Tfam gene expression of both females and males that we had determined as related to oxidative stress changed especially in the entire exercise protocols. While it increased in women after acute and chronic exercise, it increased in men after chronic exercise. The change after acute exercise is not significant. It was found that Tfam gene expression was affected for both females and males in the exercises with increased intensity. Oxidative stress and antioxidant capacity has been compared between females and males in a lot of studies up to today. There is no study among these studies that has reported difference between genders related to the oxidative stress level (Kocakulak, 2019, Gleeson, 2007). It has been emphasized that the differences are due to handling sample groups such as trained and untrained people and elderly population. Innate defense system of the body keeps the free radicals under control against the harms of the reactive oxygen species (Borras, 2003). Normally there is a delicate balance between reactive oxygen species and antioxidant activity. Exercise can increase the formation of free radical by accelerating metabolic processes. In a severe exercise, the use of oxygen in skeletal muscles can increase 100-200 times (Ahmetova, 2010). Superoxide radicals normally occur $1-2 \%$ in the mitochondrial respiratory chain. It has been report that this radical has occurred in the ubiquinone-cytochrome step being related to ubisemiquitinone oxidation (Parise et al., 2005). It is stated that the TNF- $\alpha$ and IL-1b levels increased twice and IL-6 level increased up to 100 times after a marathon race. According to studies the duration and intensity of the exercise affects the cytokine profile.

(Moldoveanu et al., 2000) performed a 20-minute cycling ergometer, 20-minute treadmill and again cycling ergometer test by dividing a 3-hour exercise into three. They took blood samples just after the exercise, 2 hours later and 24 hours later and they investigated TNF- $\alpha$, IL6, IL-1 $\beta$ gene expressions in the mononuclear cell in blood and the plasma levels. It was reported that TNF- $\alpha$, IL6, IL-1 $\beta$ plasma concentrations increased significantly just after the exercise, they continued to increase 2 hours later, and they started to return normal levels but there was no change in gene expressions. Although there are a few studies on TLR4 gene, its expression levels were investigated in both acute aerobic exercise and chronic endurance exercise, and a decrease was determined in the monocyte cell surface expression of the Toll-like receptor (Flynn, 2003) had old females have low endurance training as being 10 repetitions, 3 series and 9 trainings at $80 \%$ of 1 RM 3 days a week for 10 weeks, and TLR 4 was found lower compared to the sedentary control group. Oliveira and Gleeson had young and healthy males (VO2 Max 75\%) have total 1,5 h highly intensive interval cycling exercise 3 times a week for 2 weeks and they investigated the expression levels of TLR4 and TLR2. According to this study, TLR4 gene expression decreased in the 0 and 1st hour compared to pre-exercise, it returned to its previous level 4 hours later, and there was no change in TLR2 gene expression. No difference could be found in some studies. These results support our study and it is considered that the different results are due to the sample groups handled and training designs (OliveiraChild, 2013). In studies it is reported that immune system is not affected by intensive and long-term exercise and these result can change depending on the ages of the participants and training management (RadomAizik, 2010). It is thought that the differences between females and males occurred in our study are resulted from the intensity and duration of the exercise, individual differences, demand for oxygen, the activity levels of the individuals, energy needed during the exercise, and oxidation, which is the main principle of energy consumption. When the oxygen consumption of the participant was considered, it was determined that after the exercise it increased considerably in females and males when compared to before the exercise. Depending on the severity and intensity of the training, oxygen use capacity (Vo2 max) develops. It is known that heavy trainings affect oxygen use capacity negatively. It is seen that the change in the expressions of the genes that are determined related to immune system and oxidative stress have not affected 
the oxygen use capacities of the participants negatively. Not all genes found in humans can be actively present at the same time. Gene expression is affected by several factors.

Determining gene expression or transcription level always provides a basis for gene function studies. The data thus obtained, the number of genes studied, the number of samples included in the study in terms of the type of exercise and bears the distinction of being the first in Turkey to study this issue. According to our study, after acute exercise, 8-week interval exercises, differences occurred due to the gender and due to the characteristics of the genes that are determined related to the oxidative stress (Tfam, UCP2, UCP3) and immune system (IL-1 $\beta$, IL12B, TLR2, TLR4). However, it is not known if the increases and decreases are resulted from different exercises, from the physiological characteristics of the volunteer groups participated in the study, from the states of nutrition and rest or from the levels of the daily activity. It is thought that additional studies are necessary to make the distinction in question. However, our present findings suggest that there are significant increases and decreases in gene expression especially in some genes before and after acute and chronic exercises. These results indicate that the selected genes are activated and work by exercise, and it is thought that genetic markers may be important since they play an important role in increasing the efficacy of the exercise on individuals.

\section{ACKNOWLEDGEMENT}

This research was supported by Erciyes University Scientific Research Projects Units (Project number: TSD-12-3929).

\section{REFERENCES}

1. Ntanasis, S. J., Tzanninis, J.G., Philippou, A.A. (2013). Epigenetic regulation on gene expression induced by physical exercise. JMusculoskelet

Neuronal Interact, 13, 133-146.

2. Meier, P., Renga, M., Hoppeler, H., Baum, O. (2013). The impact of antioxidant supplements and endurance exercise on genes of the carbohydrate and lipid metabolism in skeletal muscle of mice. Cell Biochem Funct, 31, 51-59.

3. Bangi, G., Delfabbro, M., Maurş, C., Corsi, M., Melegati, G. (2000). Haematological parameters in elite rugby players during a competitive season. Clin.Lab.Haem, 28,183-188.

4. Eynon, N., Meckel, Y., Alves, A.J., Yamin, C., Sagiv, M., Goldhammer, E., Sagiv, M. (2009). Is there an interaction between PPARD T294C and PPARGC1A gly482 Ser polymorphisms and human endurance performance? Exp physiol, 11,1147-1152.
5. De Nadal, E., Ammerer, G., Posas, F. (2011). Controlling gene expression in response to stress. Nat Rev Genet, 12, 833-845.

6. Flynn, M.G., McFarlin B.K., Phillips, M.D., Stewart, L.K., Timmerman, K.L. (2003). Toll-like receptor 4 and CD14 mRNA expression are lower in resistive exercise-trained elderly women, $J$ Appl Physiol, 95(5), 1833-1842.

7. LuzScheffer, D., Ghisoni, K., AguiarJr, A.S., Latin, A. (2019). Moderate running exercise prevents excessive immune system activation. Physiology and Behavior, 204: 248-255.

8. Kumar, H., Kawai, T., Akira, S. (2009). Tolllike receptors and innate immunity. Biochem Biophys Res Commun, 388(4),621-5.

9. Lancaster, G.I., Khan, Q., Drysdale, P., Wallece, F., Jeukendrup, A.E., Drayson, M.T., Gleeson, M. (2005). The physiological regulation of toll-like receptor expression and function in humans. $J$ Physiol, 563, 945-955. 
10. Kocakulak, N.A., Hamurcu, Z., DonmezAltuntas, H., Sungur, G., Koca, F., Çoksevim, B. (2020). Effects of Exercise Performed at High Altitude on the Chromosomal DNA Damage in Human Peripheral Lymphocytes. Hacettepe J. Biol. \& Chem, 48 (1), 13-20.

11. Kocakulak, N.A. (2019). The Effect of Interval Training Program on Nuclear Factor ErythroidDerived 2-like 2 (NFE2L2/Nrf2) Gene Expression in Women. Hacettepe J. Biol. \& Chem, 47 (4), 410-414.

12. Gleeson, M. (2007). Immune function in sport and exercise. J Appl Physiol, 103,693-699.

13. Borras, C., Sastre, J., Garcfa-Sala, D., Lloret, A., Pallardo, F.V., Vina, J. (2003). Mitochond riafrom females exhibit higher antioxidant gene expression and lower oxidative damage than males. Free Radic Biol Med, 34,546-552.

14. Bruce, AR., Pearson, R., Lovejoy, F., Yu, P., Brothers., G. (1949). Variability of respiratory and circulatory performance during standardized exercise. J. Clin Invest, 28: 1431-1438.

15. Nilsson, C., Aboud, S., Karlen, K., Hejdeman, B., Urassa, W., Biberfeld, G. (2008). Optimal blood mononuclear cell isolation procedures for gamma interferon enzyme-linked immunospot testing of healthy Swedish and Tanzanian subjects. Clin Vaccine Immunol,15, 585-9.

16. Bayram, F., Diri, H., Sener, E.F., Dundar, M., Simsek, Y. (2016). Genetic expressions of thrombophilic factors in patients with Sheehan's syndrome. Gynecol Endocrinol,32(11), 908-911.

17. Jemiolo, B., Trappe, S. (2004). Single muscle fiber gene expression in human skeletal muscle: validation of internal contro lwith exercise,Biochem. Biophys. Res. Commun, 320(3), 1043-1050.

18. Catoire, M., Mensink, M., Boekschoten, M.V., Hangelbroek, R., Müller, M., Schrauwen, P., Kersten, S. (2012). Pronounced effects of acute endurance exercise on gene expression in resting and exercising human skeletal muscle, PloS One, 7 (11), e51066.

19. Ahmetova, II., Popova, D.V., Missinaa, S.S., Vinogradova, O.L., Rogozkin, V.A. (2010). Association of Mitochondrial Transcription Factor (TFAM) Gene Polymorphism with Physical Performance in Athletes. Human Physiology, 36,229-233.

20. Parise, G., Brose, A.N., Tarnopolsky, M.A. (2005). Resistance exercise training decreases oxidative damage to DNA and increases cytochrome oxidase activity in older adults. Exp Gerontol,40, 173-80.

21. Moldoveanu, A.I., Shephard, R.J., Shek, P.N. (2000). Exercise elevates plasma levels but not gene expression of IL-1b, IL-6, and TNF-a in blood mononuclear cells. J Appl Physiolog, 89,14991504.

22. Olıveira-Child, M., Leggate, M., Gleeson, M. (2013). Effects of Two Weeks of High-intensity Interval Training (HIIT) on Monocyte TLR2 and TLR4 Expression in High BMI Sedentary Men. International Journal of Exercise Science, 6, 81-90.

23. Radom-Aizik, S., Zaldivar, F., Oliver, S., Galassetti, P., Cooper, D.M. (2010). Evidence for microRNA involvement in exercise-associated neutrophil gene expression changes. J Appl Physiol ,109, 252-261. 